\title{
Discussion On The Construction of Xi'an Community Culture
}

\author{
Guanhua Dong \\ ${ }^{1}$ Xijing University, NO1,Xijing Road, Changan District of Xi'an, China,710199 \\ aemail: 258332239@qq.com
}

Keywords: Community; Construction of community culture; Participation.

\begin{abstract}
Culture construction is an important part of community construction, but there are some problems on Xi'an community culture construction. It is need to improve the participation of community residents, enhance the community cultural identity, strengthen the functional role of community culture, add adequate community cultural facilities, attract high quality human resources into community culture construction, so as to promote the sustainable development of community culture.
\end{abstract}

\section{Introduction}

With the deepening of economic system reform and the reform of political system, community began to take more and more social functions.

As the core part of urban community management, urban community culture management has become the standard to measure the comprehensive competitiveness of the community, and become the important content of the efficiency of the community management ${ }^{[1]}$. In recent years, Xi'an's urban community culture construction has achieved some success, but the happiness of the community residents and the sense of belonging is not the same as the development of the economy and the increase of the income. It is important for sustainable development of Xi'an to explore the community cultural construction.

\section{Development of Xi'an Community Culture Construction}

\section{Conception of urban community culture construction.}

Community is a group of social organizations in a certain area of the formation of a large group of people living together, is the most basic social organism ${ }^{[2]}$. Although sociologists have different definitions of community in the basic elements of the community, it is generally believed that a community should include a certain number of people, a certain range of regional, a certain size of facilities, certain characteristics of the culture, a certain type of organization ${ }^{[3]}$.

Community culture includes both the physical and social environment, the order, the style and the life style of the people, and also includes the group consciousness, the value idea and the ideal pursuit of the behavior culture of the community residents. It is a concrete manifestation of the material civilization and spiritual civilization, which is the concrete embodiment of the material civilization and spiritual civilization ${ }^{[4]}$. It is very important to improve the city function, promote the development of people's quality and accelerate the process of social modernization.

\section{Achievements of community culture construction in Xi'an.}

The purpose of community culture construction in Xi'an is to create a harmonious culture, health culture, fashion culture and open culture, so as to build a harmonious society. In recent years, with the increasingly expanding of community functions and deepening of community culture construction, many public cultural services network, including books lending, cultural activities, cultural counseling, building features, good performance, rich quality of social cultural activities center, cultural square, book reading room and other cultural facilities were built, and people can enjoy the fruits and benefits of cultural development. In recent years, Xi'an city began to explore colorful community cultural activities to establish new community relations, enhance community cohesion. 
Many communities provided skills training, health care and other activities to help residents communicate with others, made them feel the warmth of the big family.

\section{Problems of community culture construction in Xi'an City Low participation in community culture construction}

At present, most of China's community culture is promoted by the government, the community participation is not enough ${ }^{[5]}$. But there is a sense of alienation among the many community residents in Xi'an, their concern about the common interests of the community is low, and the mass of the community culture construction has not been reflected.

Facilities shortage of community culture construction.

Cultural facilities is the foundational intermediary of community culture, including the library, residents activity room, billboards, cinema and community cultural plaza. Some rich communities with complete cultural facilities carried out higher quality of cultural activities. But, many communities still have not enough cultural facilities. Some communities even have no necessary cultural centers, cultural station, compound culture, or library to run any cultural activity. In addition, the requirement for community cultural are diverse.The necessary cultural facilities, such as chess, reading, legal lectures, medical care, beauty lectures, table tennis, basketball and other needs are also different. It is difficult for community cultural facilities to keep up with the pace of the development of urban community culture.

\section{Weakening of community culture's education function.}

In general, the cultural values of the individual is often influenced by family, neighborhood, school, peer group, organization. The living community, peer groups, working environment make people form a political point of view and cultural values, and continue to affect their lives. In urban community culture construction, the impact of education is very rare. Community culture education often strenghtened by the relevant government departments, organizations and other institution. The community culture education function is difficult to fully play out.

\section{Lackness of professional talent team in the construction of community culture.}

Community cultural workers, community cultural professionals, the key members in the construction of community culture play the role of the organization, coordination, management. It is important for the development of community culture to establish a professional culture cadres team. Currently speaking, due to the ideology and the double restriction of market rules, community cultural activities in the elderly group act as the main force of the community sport, they have a great enthusiasm for the community culture activity, but their professional education and social development do not adapt the requires of community culture ${ }^{[6]}$. On the other hand, culture and education professionals, students of art colleges, art groups of professionals have strong professional skills and cultural literacy, but lack of enthusiasm for the construction of community culture. These cultural resources, has not been fully mining and utilization. Due to the lack of professional cultural workers, the development of urban community culture is unsustainable.

\section{Countermeasures for Xi'an to develop community culture construction.}

\section{Meet the cultural needs of the community residents and improve their participation}

It is very important to improve the participation degree of community residents for the construction of urban community culture in our country. First of all, it is one of the most basics step to cultivate the awareness of the community. According to cognitive psychology, the community consciousness is a set of cognitive structure system about the community. Generally speaking, the cognition of people to the community is subjective, and it often means the attitude of the residents to the community, and it directly affects the residents' inner concept, value and attitude, and the residents' participation in community activities.

In the face of the current participation awareness of urban community residents, following measures should be taken. Carry out more community activities to foster community awareness, provide interactive opportunities to enhance community residents cohesion and centripetal force. 
Provide sufficient information to increase the residents' understanding of the community, so that the majority of residents have a sense of community. Through community education, strengthen the awareness of the community, change people's attitude and views towards the community, and then enhance the sense of belonging to the community. Improve community party construction, led the whole community to participate in the formation of public participation spirit through party members and cadres exemplary role model effect. Only in this way can we make every community residents feel the warmth of the community, strengthen the community residents' awareness of the main body consciousness and the consciousness of belonging, continue to improve the participation of residents in the community cultural activities.

Improve the construction of community cultural facilities to meet the needs of community. Community cultural facilities is the material basis for the development of community culture. Because of the status of community cultural facilities in the community culture construction, it is necessary to improve the construction of community cultural facilities. We must effectively integrate the community cultural resources, realize the common construction and sharing of resources, take effective measures to change the situation of waste of cultural resources, establish a win-win way to optimize the allocation of resources in the community ${ }^{[7]}$. We should raise funds through multiple channels, and actively guide social forces to participate in the construction of community culture. Participation of all sectors of society is a very stable mode with a great potential of economic operation to develop community culture, is an important means to get more community cultural facilities.

Strengthen the community cultural identity and strengthen the function of community culture. Innovative community cultural activities to achieve the diversification of activities and content development. Community culture activity relates to a variety of cultural and artistic categories, through art lectures, training, exhibition, reading, tea, culture and art festival in a variety of ways, the cultural needs can be satisfied. Meanwhile, Residents will establish equality, friendship, cooperation of community culture in the process of participation, strengthen the social morality and healthy spirit of the conscious identity..

Actively promote the construction of urban community cultural talents, and promote the sustainable development of community culture

To achieve sustainable development for urban community culture construction, it is importment to get a number of professional, high quality, a strong sense of responsibility and dedication of community workers. So it is necessary to develop and implement policies to attract highly educated, highly qualified professional personnel to the community engaged in community culture. It is necessary to strengthen the training and continuing education of urban community culture staff. Community should strengthen cooperation with universities and research institutions, hire professional cultural workers in the community staff to carry out ideological and political, theoretical basis, social values, professional and cultural skills training. It is necessary to increase the input of funds to provide material support for the construction of community culture professional team. Through the input of funds, the wages of community workers can be continuously improved, their working environment can be improved, the attraction of outstanding professional talents can also be enhanced. With the funding of security, community workers will have more opportunities to participate in professional skills training and continuing education, will have the quality and ability to improve. So will the sustainable development of community culture..

\section{Conclusions}

City community culture construction is an important part of our country's socialist city culture construction, and it is an important content of harmonious society, harmonious city and harmonious community. Due to the rapid development of urbanization, the construction of the community must be improved. Reflecting the community's soft power, community culture construction is not only the important content of the integrated image of the community, but also the bacic elementry of a harmonious community. Because of the time of community construction, community residents' 
awareness and other reasons, there are many problems need to be solved in the construction of community culture. Therefore, it is necessary to study the construction of urban community culture. As an important part of socialist spiritual civilization, with the joint efforts of the city government, the city leaders and the general public, the urban community culture construction in Xi'an must be accelerated.

In short, the construction of urban community culture in the construction of a harmonious socialist society is of great significance. To determine the current community culture construction is the key to promote the reform of the cultural syste. It has been put in front of the party and the government as well as the National People's urgent task to Actively explore new ways of urban community culture construction. We should establish a sound long-term mechanism for the construction of urban community culture, and vigorously promote the development of socialist culture.

\section{References}

[1] Wei Du: Research on the construction of urban community culture in China(2007). In Chinese.

[2] Xiaoqin Yin: Journal of Liaoning Administrative College (2008.9), p. 8-12. In Chinese.

[3] Shaoqi Li, Xindong Lin and Ziwei Zou:. China water transport (2009.8), p. 11-19. In Chinese.

[4] Houping Zhu: Problems and Countermeasures of community culture construction in China(2011). In Chinese.

[5] Lan Li: Community culture construction and citizen happiness(2013). In Chinese.

[6] Liangen Li, Huiyang Li: New ideas of urban community culture construction in China (2013). In Chinese.

[7] Baoguang Li: Journal of Shandong Agricultural Administrators College(2008.9), p. 6-11. In Chinese. 